\title{
KAJIAN MENGENAI KEBEBASAN BERKUMPUL DAN BERSERIKAT PASAL 28E AYAT (3) UNDANG-UNDANG DASAR 1945 MELALUI ORGANISASI KEMASYARAKATAN KAITANNYA DENGAN TEORI KEDAULATAN RAKYAT DAN HAK ASASI MANUSIA
}

\author{
Bahar Elfudllatsani \\ Email:baharsany@gmail.com \\ Mahasiswa Program Studi Magister Ilmu Hukum Program Pascasarjana \\ Fakultas Hukum Universitas Sebelas Maret Surakarta \\ Isharyanto \\ Email:isharyantoisharyanto8@gmail.com \\ Dosen Fakultas Hukum Universitas Sebelas Maret Surakarta \\ Agus Riwanto \\ Email: agusriwanto@staff.uns.ac.id \\ Dosen Fakultas Hukum Universitas Sebelas Maret Surakarta
}

\begin{abstract}
Today there is an increasingly strong view that the organizational community in all three domains, namely the state, the society, and the business world must be in a balanced and mutually supportive position to sustain the dynamics of the nation's progress. In this article will be discussed about the arrangement of freedom of assembly and association in Article 28E Paragraph (3) of the 1945 Constitution as well as the theory of people's sovereignty and human rights view freedom of assembly and association. This study uses normative legal research. Legal, historical, conceptual, and philosophical approaches were made in this study. State arrangements on the various forms and types of the organization need to be taken into account the importance of (i) the principle of separation (decoupling) (ii) the principles of "legal and onstitutional organization", (iii) the principles of "good governance", and (iv) the need for "Organizational empowerment" (v) the embodiment of the principle of "freedom of association" (vi) ensures, reflects, and does not diminish the meaning of principles of freedom of thought, freedom of thought, and freedom of expression. The Asian values referred to in freedom of association, assembly and expression are formulated through political concepts in these Asian countries.
\end{abstract}

Keywords: civil organization; freedom of assembly and associaton; popular sovereignty theory and human rights

\begin{abstract}
Abstrak
Dewasa ini berkembang pandangan yang semakin kuat bahwa komunitas organisasi di ketiga ranah, yaitu negara, masyarakat, dan dunia usaha itu haruslah berada dalam posisi yang seimbang dan saling menunjang satu sama lain untuk menopang dinamika kemajuan bangsa. Dalam artikel ini akan dibahas mengenai pengaturan kebebasan berkumpul dan berserikat dalam pasal 28E ayat (3) undang-undang dasar 1945 dan juga teori kedaulatan rakyat dan hak asasi manusia memandang kebebasan berkumpul dan berserikat.Penelitian ini menggunakan penelitian hukum normatif. Pendekatan perundang-undangan, historis, konseptual, dan filsafat dilakukan dalam penelitian
\end{abstract}


ini. Pengaturan-pengaturan oleh negara terhadap aneka bentuk dan jenis organisasi tersebut, perlu diperhatikan pentingnya (i) prinsip pemisahan (decoupling) (ii) prinsip "legal and onstitutional organization", (iii) prinsip "good governance", dan (iv) kebutuhan akan "organizational empowerment" (v) perwujudan prinsip "freedom of association" (vi) menjamin, mencerminkan, dan tidak mengurangi arti dari prinsip-prinsip kebebasan berkeyakinan, kebebasan berpikir, dan kebebasan berpendapat. Nilai-nilai Asia yang dimaksud dalam kebebasan berserikat, berkumpul dan mengeluarkan pendapat dirumuskan lewat konsep politis dalam negara-negara asia tersebut.

Kata Kunci: Organisasi Masyarakat; Kebebasan berkumpul dan berserikat; teori kedaulatan rakyat dan Hak Asasi Manusia.

\section{A. Pendahuluan}

Prinsip kebebasan atau kemerdekaan berserikat ditentukan dalam Pasal 28 UUD 1945 (pra reformasi) yang berbunyi, "Kemerdekaan berserikat dan berkumpul, mengeluarkan pikiran dengan lisan dan tulisan dan sebagainya ditetapkan dengan undang-undang”. Pasal 28 asli ini sama sekali belum memberikan jaminan konstitusional secara tegas dan langsung, melainkan hanya menyatakan akan ditetapkan dengan undang-undang. Namun, setelah reformasi, melalui Perubahan Kedua UUD 1945 pada tahun 2000, jaminan konstitusional dimaksud tegas ditentukan dalam Pasal 28E ayat (3) UUD 1945 yang menyatakan, "Setiap orang berhak atas kebebasan berserikat, berkumpul, dan mengeluarkan pendapat". Dengan demikian UUD 1945 secara langsung dan tegas memberikan jaminan kebebasan untuk berserikat atau berorganisasi (freedom of association), kebebasan berkumpul (freedom of assembly), dan kebebasan menyatakan pendapat (freedom of expression), tidak hanya bagi setiap warga negara Indonesia, tetapi juga bagi setiap orang yang artinya termasuk juga orang asing yang berada di Indonesia (Jimlyschool.com diakses tanggal 22 November 2017).

Dalam kehidupan berbangsa, kita dapat membedakan adanya jenis-jenis organisasi yang bekerja dalam tiga ranah kehidupan bersama, yaitu dalam ranah negara (state), masyarakat (civilsociety), dan dunia usaha (market). Pembedaan dan bahkan pemisahan ketiganya harus lah dijadikan perspektif baru dalam membangun pengertian-pengertian mengenai organisasi modern, termasuk mengenai organisasi kemasyarakatan sejalan dengan perkembangan ide mengenai prinsip "legalandconstitutionalgovernment" dan gagasan "goodgovernance ". Bahkan dewasa ini berkembang pula pandangan yang semakin kuat bahwa komunitas organisasi di ketiga ranah negara, masyarakat, dan dunia usaha itu haruslah berada dalam posisi yang seimbang dan saling menunjang satu sama lain untuk menopang dinamika kemajuan bangsa.

Pasang surutnya aturan mengenai Organisasi Kemasyarakatan di Indonesia begitu dinamis. Mulai dari diresmikannya Undang-Undang Nomor 8 Tahun 1985 tentang Organisasi Kemasyarakatan, dimana asas tunggal Pancasila diharuskan menjadi dasar ideologi negara dan warga negara. Nahdlatul Ulama dan Muhammadiyah adalah dua Organisasi Kemasyarakatan yang ikut meresmikan Undang-Undang ini. Bahkan, ketika MUI didirikan pada 1975, organisasi ulama ini langsung menjadikan Pancasila sebagai dasar ideologi organisasi. Pancasila berhasil menjadi ideologi bangsa dan negara.

Reformasi tahun 1998, pasca kekalahan rezim Suharto, model Pancasila tertutup ala Suharto ini menjadi salah satu sasaran gugatan utama kalangan aktivis pada masa itu. 
Mereka menuduh Suharto menjadikan Pancasila sebagai alat untuk menghalangi kebebasan berserikat, berkumpul dan menyatakan pendapat. Dengan itu, Tap MPR Nomor XVIII Tahun 1998 menghapus asas tunggal dan sekaligus keberlakuan Pasal 2 ayat (1) Undang-Undang Nomor 8 Tahun 1985 yang menyebutkan "organisasi kemasyarakatan berasaskan Pancasila sebagai satu-satunya asas". Sejak penerbitan Tap MPR ini, Pancasila menjadi hanya sebagai asas negara; bukan sebagai ideologi warga negara karena warga negara melalui ormas boleh menggunakan ideologi di luar Pancasila. Tidak heran kemudian muncul banyak ormas yang menggunakan agama sebagai dasar ideologi mereka. Desakralisasi Pancasila ini berlaku bahkan hingga tahun 2013 dengan diterbitkannya Undang-Undang Nomor 17 Tahun 2013 tentang Organisasi Kemasyarakatan, yang mengembalikan Pancasila sebagai ideologi dan warga negara, yang kemudian semakin dikuatkan lagi oleh Peraturan Pemerintah Pengganti Undang-Undang Nomor 2 Tahun 2017 tentang perubahan atas Undang-Undang Nomor 17 Tahun 2013 tentang Organisasi Kemasyarakatan (Syafiq Hasyim. Perppu Ormas dan Demokrasi Pancasila. Dalam Beritagar.id 08.15 WIB-Senin 17 Juli 2017 diakses tanggal 29 Agustus 2017 Jam 20.00).

Terbitnya Perppu Nomor 2 Tahun 2017 tentang perubahan atas Undang-Undang Nomor 17 Tahun 2013 tentang Organisasi Kemasyarakatan sempat menimbulkan pro dan kontra terkait kebebasan berserikat, berkumpul dan menyatakan pendapat. Di sini peneliti merasa perlu untuk mengkaji mengenai hal tersebut dikaitkan dengan peran Nahdlatul Ulama dan Muhammadiyah yang menjadi organisasi terbesar di Indonesia dan juga paling dikenal di Indonesia menurut survei yang dilakukan Alvara Research Center (Survei : NU, Muhammadiyah dan FPI Tiga Besar "Top Of Mind" Organisasi Islam di Indonesia. Kompas. com Senin 30 Januari 2017 Pukul 20.22 WIB diakses tanggal 1 September 2017 Pukul 13.35).

Bagaimanakah Pasal 28E ayat (3) Undang-Undang Dasar 1945 mengatur kebebasan berkumpul dan berserikat melalui Organisasi Kemasyarakatan dan Bagaimana teori kedaulatan rakyat dan hak asasi manusia memandang kebebasan berkumpul dan berserikat, inilah yang dikaji dalam artikel ini.

\section{B. Metode Penelitian}

Penelitian ini menggunakan penelitian hukum normatif karena metode yang digunakan dalam penelitian ini dengan cara meneliti kepustakaan yang ada (Soerjono Soekanto dan Sri Mamudji. 2009: 13-14). Kemudian dilakukan Pendekatan perundang-undangan, historis, konseptual, dan filsafat agar semakin mempertajam kajian dalam penelitian ini.

\section{Hasil Penelitian dan Pembahasan}

\section{Pengaturan Kebebasan Berkumpul dan Berserikat dalam Pasal 28E ayat (3) Undang-Undang Dasar 1945 melalui Organisasi Kemasyarakatan}

Kebebasan berbicara (Freedom of speech) adalah kebebasan yang mengacu pada sebuah hak untuk berbicara secara bebas tanpa adanya tindakan sensor atau pembatasan akan tetapi dalam hal ini tidak termasuk dalam hal untuk menyebarkan kebencian. dapat diidentikan dengan istilah kebebasan berekspresi yang terkadang digunakan 
untuk menunjukkan bukan hanya kepada kebebasan berbicara lisan, akan tetapi, pada tindakan pencarian, penerimaan dan bagian dari informasi atau ide apapun yang sedang dipergunakan (Peiroll Gerard Notanubun. 2014. Tinjauan Yuridis Terhadap Kebebasan Berbicara Dalam Ketentuan Pasal 27 Ayat 3 Uu Nomor 11 Tahun 2008 Tentang Ite Dalam Hubungan Dengan Pasal 28 Uud 1945. Jurnal Ilmu Hukum Edisi Mei-November 2014. Mimbar Keadilan).

Pengaturan-pengaturan oleh negara terhadap aneka bentuk dan jenis organisasi tersebut, perlu diperhatikan pentingnya (i) prinsip pemisahan (decoupling) antar ranah negara, masyarakat, dan dunia usaha itu, (ii) prinsip "legal and onstitutional organization", (iii) prinsip "good governance", dan (iv) kebutuhan akan "organizational empowerment" dalam rangka (v) perwujudan prinsip "freedom of association" yang (vi) tetap menjamin, mencerminkan, dan tidak mengurangi arti dari prinsip-prinsip kebebasan berkeyakinan, kebebasan berpikir, dan kebebasan berpendapat (freedom of belief, freedom of thought, and freedom of expression).

Di masing-masing ranah, terdapat beraneka macam dan jenis organisasi yang dibentuk oleh pendirinya dengan maksud untuk mencapai tujuan bersama. Organisasi dalam ranah struktur negara tersusun atas dasar jabatan-jabatan secara horizontral, vertical dan bahkan diagonal, sehingga oleh Logemann organisasi negara itu disebut sebagai organisasi jabatan (ambten organisatie). Secara umum, organisasi jabatan dibedakan dalam cabang-cabang:

1) Cabang eksekutif.

2) Cabang legislative.

3) Cabang Judisial;

4) Cabang-cabang campuran atau cabang lainnya.

Sementara itu, organisasi dalam ranah dunia usaha dapat dibedakan antara persekutuan orang dan persekutuan kekayaan kapital. Organisasi yang dapat dikategorikan sebagai persekutuan orang adalah Koperasi, sedangkan organisasi yang merupakan perkumpulan modal atau capital adalah perseroan terbatas yang tersusun atas nilai saham. Organisasi negara juga ada yang bersifat persekutuan kekayaan yang dipisahkan dari kekayaan negara, yaitu Badan Hukum Milik Negara (BHMN) dan Badan Usaha Milik Negara (BUMN).

Sehubungan dengan itu, organisasi dalam lingkungan kemasyarakatan juga dapat kita bedakan antara persekutuan orang dan persekutuan kekayaan itu. Bahkan, organisasi kemasyarakatan ada pula yang merupakan pesekutuan organisasi atau institusi, seperti badan kerjasama perguruan tinggi, dan sebagainya. Yang termasuk organisasi kemasyarakatan dengan kategori persekutuan kekayaan adalah:

a) Yayasan yang diatur berdasarkan UU No. 28 Tahun 2004 tentang Yayasan; dan

b) Badan wakaf yang diatur berdasarkan UU tentang Wakaf.

Sedangkan organisasi kemasyarakatan atau organisasi masyarakat dengan kategori persekutuan organisasi dapat terdiri atas organisasi-organisasi berbadan hukum atau organisasi bukan berbadan hukum. Di samping itu, ada pula kemungkinan organisasi yang menjadi anggota itu, tidak termasuk kategori organisasi kemasyarakatan. Misalnya, Asosiasi Pemerintahan Daerah, Asosiasi DPRD, Asosiasi Gubernur, Asosiasi Walikota, dan sebagainya. Apakah asosiasi-asosiasi semacam ini dapat dikategorikan sebagai 
organisasi kemasyarakatan atau bukankah? Jika asosiasi-asosiasi ini didaftarkan untuk mendapatkan status badan hukum, dapatkah diterima dan diberikan status badan hukum? Menurut saya, yang seharusnya diterima untuk membentuk organisasi bukanlah organisasi negaranya seperti Gubernur, Walikopta, dan DPRD, tetapi orang per orang yang menduduki jabatan-jabatan Gubernur, Bupati, Walikota, atau Anggota DPRD yang bersangkutan. Jadi yang berorganisasi bukanlah lembaganya melainkan orangnya. Kalau demikian maka nama organisasi Asosiasi Pemerintahan Daerah, Asosiasi Gubernur, dan sebagainya itu harus dipersoalkan, apalagi jika kegiatan organisasi itu menggunakan anggaran belanja daerah.

Sementara itu, organisasi kemasyarakatan yang termasuk kategori persekutuan orang adalah:

a) Partai Politik yang diatur dengan UU tentang Partai Politik;

b) Perkumpulan (Vereeniging) berbadan hukum yang diatur berdasarkan Staatsblad 1870 No. 64;

c) Lembaga Swadaya Masyarakat yang diatur berdasarkan UU Lingkungan Hidup Tahun 1982; dan

d) Organisasi Kemasyarakatan yang diatur berdasarkan Undang-Undang Nomor 2 Tahun 2017 tentang perubahan atas Undang-Undang Nomor 17 Tahun 2013 tentang Organisasi Kemasyarakatan.

Di samping itu, di pelbagai bidang kegiatan partisipasi masyarakat yang terkait dengan kegiatan instansi-instansi pemerintahan, terdapat pula berbagai macam organisasi yang diatur tersendiri instansi yang bersangkutan. Misalnya, organisasi masyarakat penyelenggara dakwah keagamaan, pendidikan, kesehatan, social, lingkungan hidup, dan sebagainya.

Untuk itu, kategorisasi dimaksud dapat dibedakan antara (1) status badan hukum dan bukan badan hukumnya dan (2) kategorinya sebagai persekutuan orang atau persekutuan kekayaan. Di samping itu, kategorisasi dapat pula dilihat dari (3) susunan organisasinya yang bersifat massal atau merupakan sistem unit. Jika keanggotaan bersifat massal, maka organisasi itu biasanya disebut sebagai organisasi massa dengan susunan yang terdiri atas cabang-cabang dan ranting, seperti Nahdhatul Ulama dan Muhammadiyah. Sedangkan keanggotaan organisasi unit tidak bersifat massal, melainkan terbatas, sehingga struktur organisasinya hanya sebagai 1 unit organisasi, tidak memiliki cabang di daerah-daerah, melainkan hanya kantor perwakilan saja. Selain itu, organisasi kemasyarakatan dapat pula dibedakan dari (4) lingkup kegiatannya yang bersifat umum atau bersifat khusus menurut bidang-bidang tertentu saja, misalnya hanya di bidang pendidikan, atau kesehatan saja. Dalam praktik, ada organisasi dengan keangotaan yang bersifat massal dan dengan kegiatan yang bersifat umum, mencakup semua bidang yang sangat luas, seperti organisasi Nahdhatul Ulama dan Muhammadiyah.

\section{Teori Kedaulatan Rakyat dan Hak Asasi Manusia Memandang Kebebasan Berkumpul dan Berserikat}

Hak Asasi Manusia yang dideklarasikan melalui DUHAM mempunyai keinginan yang kuat agar hak asasi manusia dapat berlaku universal. Untuk menjadi suatu hal 
yang membumi maka diperlukan kekuatan yang kuat dan mengakar yang dapat disebut sebagai ideologi universal. Ideologi berasal dari bahasa latin, yaitu ideos yang berarti pemikiran dan logis yang berarti logika, ilmu, pengetahuan. Sehingga makna ideologi adalah ilmu mengenai keyakinan atau cita-cita (Ali Syariati, 1982: 7). Dalam pengertian lain, ideologi diartikan sebagai suatu pandangan atau sistem nilai yang menyeluruh dan mendalam yang dipunyai oleh suatu masyarakat tentang bagaimana cara yang sebaiknya, yaitu secara moral dianggap benar dan adil, mengatur tingkah laku bersama dalam berbagai segi kehidupan duniawi mereka (Alfian, 1981: 187). Ideologi juga memiliki arti konsepsi manusia tentang politik, sosial, ekonomi dan kebudayan untuk diterapkan ke dalam suatu tatanan masyarakat atau negara (Sukarna, 1981: 113). Ideologi yang merupakan tatanan sistem nilai, seperti yang dikatakan oleh Gramsci, inilah yang dapat membumikan hak asasi manusia sebagai nilai universal.

Hak Asasi Manusia adalah hak dasar atau pokok manusia yang dibawa sejak lahir sebagai anugrah Tuhan Yang Maha Esa, bukan pemberian penguasa. Hak ini sifatnya sangat mendasar atau fundamental bagi hidup dan kehidupan manusia yang merupakan hak kodrati yang tidak bisa terlepas dari kehidupan manusia (Erdiansyah,Artikel Pada Jurmal Konstitusi Vol.III,No.2 November 2010,hlm.146). Hak asasi manusia yang dideklarasikan itu sendiri lebih banyak menunjukkan reaksi atas tindakan-tindakan negatif yang terjadi. Hak asasi manusia versi liberalisme hadir dari kekecewaan kepemimpinan gereja yaitu pada masa pencerahan di Eropa (Renaissance). Untuk itu hasil yang timbul dalam konsep pemikiran hak asasi manusia adalah hak sebagai individu.

Memasukkan hak-hak asasi manusia ke dalam pasal-pasal konstitusi merupakan salah satu ciri konstitusi moderen. Setidaknya, dari 120an konstitusi di dunia, ada lebih dari 80 persen diantaranya yang telah memasukkan pasal-pasal hak asasi manusia, utamanya pasal-pasal dalam DUHAM. Perkembangan ini sesungguhnya merupakan konsekuensi tata pergaulan bangsa-bangsa sebagai bagian dari komunitas internasional, utamanya melalui organ Perserikatan Bangsa-Bangsa (PBB) (R. Herlambang Perdana Wiratraman, Jurnal Hukum Panta Rei, Vol. 1, No. 1 Konsorsium Reformasi Hukum Nasional, Desember 2007 hal. 3).

Berbeda dengan hak asasi manusia versi republikanisme yang keras disampaikan oleh Hannah Arendt yang senada dengan madzhab Frankfurt dan para kaum komunitarian Amerika, bahwa hak asasi manusia adalah kesepakatan politis yang dapat dijamin negara atau komunitas. Adanya pengakuan terhadap suatu hak terjadi karena kesepakatan politis. Jika tidak ada negara maka kesepakatan politis itu tidak ada. Hak individualis yang dicanangkan oleh kaum liberalisme bagi Hannah Arendt justru terdengar tragis. Ia mencontohkan kasus pembasmian yang dilakukan oleh Nazi. Ada tiga tahapan pembunuhan yang dilakukan, yaitu terhadap person yuridis, person moral, dan individualitas person. Menurut Arendt jika maunsia kehilangan identitas kolektif, moral dan individu, suatu hak minimal yang masih boleh dimilikinya, akan tampak berlebihan (F.Budi Hardiman, 2011: 31-32).

Kewajiban negara sebagai penanggung jawab utama dalam pemenuhan HAM itu secara jelas diatur dalam Hukum internasional dan hukum nasional. Dalam tataran hukum internasional tonggak sejarah keberhasilan perjungan pengakuan dan penghormatan nilai- 
nilai HAM ditandai dengan lahirnya Dekalarasi Umum Hak Asasi Manusia (DUHAM) (Veronica Agnes, Eddy Mulyono, dan Rosita Indrayanti Artikel Ilmiah Mahasiswa).

Konsep tentang Hak Asasi Manusia (HAM) bukan merupakan hal baru bagi bangsa Indonesia. Salah satu komitmen Indonesia terhadap penghormatan dan jaminan perlindungan HAM terkandung dalam sila kedua Pancasila, dasar negara dan falsafah hidup bangsa Indonesia, yaitu “Kemanusiaan Yang Adil dan Beradab". Undang-Undang Dasar 1945 yang telah lahir sebelum DUHAM memiliki perspektif hak asasi manusia yang cukup progresif (R. Herlambang Perdana Wiratraman, Jurnal Hukum Yuridika Fakultas Hukum Universitas Airlangga, Vol. 20 No. 1, Januari-Februari 2005 hal. 32-33.). Kebebasan dasar dan hak-hak dasar itulah yang disebut HAM yang melekat pada manusia secara kodrati sebagai anugerah Tuhan. Hak ini tidak dapat diingkari. Pengingkaran terhadap hak tersebut berarti mengingkari martabat kemanusiaan. Oleh karena itu, Negara, Pemerintah atau Organisasi apapun mengemban kewajiban untuk mengakui dan melindungi HAM pada setiap manusia tanpa kecuali (Shinta Dewi Rismawati, Jurnal Hukum Islam volume 10, nomor 1 Juni 2012. Hlm 24)

Islam mempunyai anti tesis yang berbeda dengan mendeklarasikan DUHAMIS. Dalam pembukaannya menetapkan tiga pokok yang sangat penting untuk memahami ide hak asasi manusia Islam. Pertama, klaim bahwa Islam sebelum abad ke-14 sudah mendasarkan hak-hak asasi manusia. Kedua, perintah misioner bahwa kaum muslim memiliki kewajiban menyebarkan kepada semua manusia dan membebaskan melalui Islam. Dan ketiga, teologi bahwa penerimaan atas hak asasi manusia Islam ini melukiskan jalan yang benar menuju pembangunan sebuah masyarakat Islam sejati (F.Budi Hardiman, 2011: 51-52). Ketiga hal ini menurut saya adalah bentuk gerakan Islam konservatif. Hal ini kurang lebih sama dengan konsep pemikiran hak asasi manusia dalam DUHAM dengan konsep kunci berupa person, individu, otonomi, hak-hak kodrati yang tak dapat diasingkan dalam konsep khas kultur Kristiani Barat.

Hal ini semakin kompleks setelah pada abad ke-20 muncul pendapat di dalam bab buku yang berasal dari pengamatan Clifford Geertz tentang politik identitas yang mulai merebak dan diberi judul "apakah suatu negeri, jika ia bukan suatu bangsa?"( Clifford Geerts. Welt in Stucken. Kultur und Politik am Ende des 20. Jahrunders. Passagen-Verlag. Wien. 1996 dalam buku F. Budi Hardiman.). Pertanyaan seperti itu di era globalisas dan migrasi ini seperti gaung dari masa silam yang mungkin makin salah untuk diartikan. Bangsa seharusnya lebih dilihat sebagai civic nation daripada ethnic nation. Politik yang dibayangkan oleh Geertz yaitu menangani masalah SARA ataupun separatisme sebagai masalah penataan politis dan keadilan, yakni sebagai persoalan pembagian hak-hak dalam negara. Profesor Will Kymlicka menawarkan politik multikulturalisme untuk memenuhi harapan tersebut.

Pasca perang dingin berakhir, liberalisme barat sama sekali tidak memnangi hubungan internasional dan juga tidak berada pada akhir sejarah diakuinya liberalisme secara global. Filsuf Amerika, Francis Fukuyama bahkan meyakini dunia memiliki banyak motif untuk menekankan perbedaan-perbedaan internasional dan untuk menghasilkan gesekan baru. Setelah sirnanya ketegangan-ketegangan antara kapitalisme dan komunisme, di masa depan (bahkan mungkin sudah dimulai) akan diisi dengan ketegangan kultural. Samuel P. Huntington bahkan mengungkapkan bahwa konflik utama politik global akan 
berlangsung antara bangsa-bangsa dan kelompok-kelompok dari berbagai kebudayaan (Samuel P. Huntington. “The Clash of Civilization?”, dalam Foreign Affairs, Musim Panas. 1993 dalam buku F. Budi Hardiman).

Persoalan mengenai keinginan dari DUHAM yang konsepnya seperti yang telah disebutkan di atas berasal dari konsep barat, terjadi pertentangan karena hal itu dianggal sebagai kedok kolonisasi baru. Nilai-nilai barat yang diklaim sebagai universal diasalkan pada tuntutan dasar Revolusi Amerika dan Revolusi Perancis yang dapat kita rangkum dalam konsep hak-hak asasi manusia. Sedangkan pada negara-negara Asia Timur, hakhak asasi manusia itu dicantumkan di dalam konstitusi masing-masing sebagai hak-hak dasar (Grundrechte). Tindakan-tindakan pembebasan dari tuan-tuan penjajah persis mengacu pada nilai-nilai tersebut.

Nilai-nilai Asia yang dimaksud dan masih dijadikan perdebatan adalah stereotip berkenaan mengenai: (1) mengutamakan kepentingan-kepentingan komunitas di atas hak-hak dan kebebasan-kebebasan individu; (2) bersikap konsensual, paternalistis dan kekeluargaan; (3) hormat dan patuh kepada otoritas dam berpikir dengan berorientasi pada tatanan sosial; (4) mengutamakan hubungan-hubungan personal; (5) lebih memilih harmoni daripada kompetisi atau konfrontasi; (6) mengambil keputusan dengan pola hirarkis dan vertikal; (7) belajar dengan meniru dan mengasuh dengan hukuman; (8) mengutamakan etika dan moral di atas hukum; dan (9) memiliki keutamaan-keutamaan sosial seperti kerajinan, kerja keras, disiplin diri dan kepatuhan. Nilai-nilai tersebut dirumuskan lewat konsep-konsep politis: ideologi nasional di Singapura, Rukunegara di Malaysia dan Pancasila di Indonesia.

Pada Pasal 1 ayat (2) UUD 1945 (redaksi baru) ditetapkan, "Kedaulatan berada di tangan rakyat dan dilaksanakan menurut Undang - Undang Dasar”. Pasal konstitusi dimaksud memuat paham konstitusionalisme. Rakyat pemegang kedaulatan tertinggi terikat pada konsititusi. Kedaulatan rakyat dilaksanakan menurut UUD, tidak boleh dijalankan atas dasar the ruling of the mob (M. Laika Marzuki Jurnal Konstitusi Volume 7 Nomor 4. Agustus 2010 Hlm. 5).

\section{Simpulan}

Pengaturan-pengaturan oleh negara terhadap aneka bentuk dan jenis organisasi tersebut, perlu diperhatikan pentingnya (i) prinsip pemisahan (decoupling) antar ranah negara, masyarakat, dan dunia usaha itu, (ii) prinsip "legal and onstitutional organization", (iii) prinsip "good governance", dan (iv) kebutuhan akan "organizational empowerment" dalam rangka (v) perwujudan prinsip "freedom of association" yang (vi) tetap menjamin, mencerminkan, dan tidak mengurangi arti dari prinsip-prinsip kebebasan berkeyakinan, kebebasan berpikir, dan kebebasan berpendapat (freedom of belief, freedom of thought, and freedom of expression).

Nilai-nilai Asia yang dimaksud dalam kebebasan berserikat, berkumpul dan mengeluarkan pendapat dirumuskan lewat konsep politis dalam negara-negara asia tersebut. Hal ini terjadi di Singapura dengan ideologi nasional, Malaysia dengan Rukunegara dan Indonesia dengan Pancasila. 


\section{E. Saran}

Kebebasan berserikat, berkumpul dan mengeluarkan pendapat adalah bagian dari Hak Asasi Manusia yang harus diperhatikan oleh Pemerintah. Namun, perlu disadari pula bahwa kebebasan tersebut bukan tidak tak terbatas. Pemerintah melalui Kementerian Hukum dan HAM dan Kementerian Dalam Negeri serta Kesatuan Kebangsaan dan Politik daerah mempunyai kewenangan untuk membatasi kebebasan tersebut dengan tetap memperhatikan prinsip kebebasan tersebut.

Langkah pemerintah mengeluarkan Undang-Undang Nomor 2 Tahun 2017 tentang perubahan atas Undang-Undang Nomor 17 Tahun 2013 tentang Organisasi Kemasyarakatan cukup progresif. Namun, perlu diperhatikan oleh pemerintah melalui Kementerian Hukum dan HAM dan Kementerian Dalam Negeri serta Kesatuan Kebangsaan dan Politik daerah adalah adanya kerjasama dengan organisasi kemasyarakatan yang lain agar tindakan pemerintah tidak sewenang-wenang.

\section{F. Daftar Pustaka}

Ali Syariati. 1982. Tugas Cendekiawan Muslim. Yogyakarta: Shalahudin Pers.

Alfian.1981. Pemikiran dan Perubahan Politik Indonesia. Jakarta: Gramedia.

Clifford Geerts. 1996. Welt in Stucken. Kultur und Politik am Ende des 20. Jahrunders. Passagen-Verlag. Wien.

F. Budi Hardiman. 2011. Hak-hak Asasi Manusia - Polemik dengan Agama dan Kebudayaan. Yogyakarta: Kanisius.

Samuel P. Huntington. 1993. "The Clash of Civilization?”, Foreign Affairs, Musim Panas.

Soerjono Soekanto dan Sri Mamudji. 2009. Penelitian Hukum Normatif Suatu Tinjauan Singkat. Cetakan ke-11. Jakarta: PT Raja Grafindo Persada.

Sukarna. 1981. Suatu Studi Ilmu Politik Ideologi. Bandung: Alumni.

Erdiansyah. 2010.Perlindungan HAM dan Pembangunan Demokrasi Di Indonesia, Artikel Pada Jurmal KonstitusiVol.III,No.2 November 2010. Riau: BKK Fakultas Hukum Universitas Riau Kerjasama dengan Mahkamah Konstitusi

M. Laika Marzuki. 2010. Konstitusi dan Konstitusionalisme. Jakarta:Jurnal Konstitusi Volume 7 Nomor 4. Agustus 2010

Peiroll Gerard Notanubun. 2014.Tinjauan Yuridis Terhadap Kebebasan Berbicara Dalam Ketentuan Pasal 27 Ayat 3 Undang-Undang Nomor 11 Tahun 2008 Tentang ITE Dalam Hubungan Dengan Pasal 28 UUD NRI 1945. Surabaya:Jurnal Ilmu Hukum Edisi Mei- November 2014. Mimbar Keadilan 
R. Herlambang Perdana Wiratraman. 2005.Konstitusionalisme dan Hak Asasi Manusia: Konsepsi Tanggung Jawab Negara dalam Sistem Ketatanegaraan Indonesia. Surabaya: Jurnal Hukum Yuridika Fakultas Hukum Universitas Airlangga, Vol. 20 No. 1, Januari-Februari 2005

R. Herlambang Perdana Wiratraman. 2007. Hak-Hak Konstitusional Warga Negara Setelah Amandemen UUD 1945: Konsep, Pengaturan dan Dinamika Implementasi, Jakarta: Jurnal Hukum Panta Rei, Vol. 1, No. 1 Konsorsium Reformasi Hukum Nasional, Desember 2007

Shinta Dewi Rismawati. Pengaruh. 2012. Globalisasi Terhadap Politik Hukum Berbasis Perlindungan Ham Di Indonesia. Jurnal Hukum Islam volume 10, nomor 1 Juni 2012 